\title{
Postpartum Psikoz
}

\section{Postpartum Psychosis}

\author{
Emine Füsun Akyüz Çim
}

\section{TC Sağhlk Bakanlĭğ Van Bölge Eğitim ve Arastırma Hastanesi Psikiyatri Kliniğgi, Van}

\begin{abstract}
ÖZET
Lohusalık sürecinde gözlenen psikopatolojik durumlar içerisinde, klinik tablo ve olası sonuçlar açısından en riskli olan durum postpartum psikozdur. Gebelik ve lohusa döneminde meydana gelen psikososyal değişim, uykusuzluk, hormonal faktörlerin oluşturduğu kuvvetli stresörler ile birlikte, genetik yatkınlık psikozun ortaya çıkışını kolaylaştırır. Postpartum psikozun prevelansı seyrek olsa da, özkıyım ve bebeğe karşı ciddi homosidal risk göz önüne alındığında, acil ve analitik müdahalenin önemi artmaktadır.
\end{abstract}

Anahtar Kelimeler: Gebelik, postpartum, psikoz

\begin{abstract}
Among the psychopathological conditions observed during the puerperium period, the most risky condition in terms of clinical picture and possible outcomes is postpartum psychosis. Psychosocial change during pregnancy and postnatal period, insomnia, genetic predisposition facilitates the emergence of psychosis with strong stressors caused by hormonal factors. Although the prevalence of postpartum psychosis is rare, the importance of urgent and analytical intervention is heightened when serious homicidal risk to suicide and babies is taken into account.
\end{abstract}

Key Words: Pregnancy, postpartum, psychosis

Postpartum psikoz olgularının hezeyanları ve hallüsinatuar yaşantısı sıklıkla bebek ile ilgilidir. Bebeğin öldüğüne, anomalili doğduğuna ilişkin inançlar1 ve bebeğe zarar vermesini söyleyen işitsel varsanılar1 olabilmektedir. Bu belirtiler kümesi öz kıyım ve/veya bebeğe zarar verme ihtimalini arttırmaktadır. Kognitif bozulma ve deliryum benzeri belirtiler ise; mental konfüzyon, intruziv ve bizar düşüncelere karşı karasız tutum, iyilik halini takip eden psikotik semptomlar şeklinde olabilmektedir $(5,6)$.

Gebelik ve postpartum dönemde, başta endokrin sistem olmakla birlikte, tüm vücutta fizyolojik değissiklikler meydana gelmektedir. Özellikle vasküler ve hematopoetik sistemde meydana gelen değişikler, serebral venöz tromboz gibi organik psikotik tablolara neden olabilmektedir. Ayrica Sydenam koresi, Wernicke ensefalopatisi, infektif deliryum (sepsis, ensefalit), epilepsi, hipopituitarizm, alkol yoksunluk sendromu, deliryum ve psikotik belirtilerin bir arada görülebileceği, postpartum dönemde oluşabilecek organik psikoz tabloları arasında yer almaktadır. $\mathrm{Bu}$ nedenle klinisyen olas1 organik etyoloji açısından allert olmalıdır. 


\section{Etyoloji ve Risk Faktörleri}

Lohusalık döneminde psikoza yatkınlığ1 olan olgularda, gebelik ve doğumun beraberinde getirdiği psikososyal stresörler obstetrik komplikasyonlar, gece saatlerinde doğum yapma ya da doğum sürecinin uzamasından kaynaklanan uykusuzluk psikotik atağın oluşumunu kolaylaştırmaktadır $(6,7)$.

Postpartum psikozun olas1 etyolojik faktörleri incelendiğinde, literatürde genellikle hormonal belirteçler üzerinde yoğunlaşılmaktadır. Literatürde özellikle östrojen ve tiroid hormonları incelenmiştir. Östrodiol, psikotik hastalık patogenezinde rol oynadığı düşünülen ve biyolojik açıdan kadınlar için dominant olan önemli bir sex steroididir. Sex steroidleri merkezi sinir sistemine biyokimyasal özellikleri nedeni ile kolayca geçebilmekte, bilişsel-kognitif faaliyetlerde direk etkili olabilmektedirler. Kadınların yaşam sürecinde östrojen düzeylerinde ciddi dalgalanmaların olduğu, postpartum dönem, peri ve postmenapozal dönemler, menstural siklusun erken foliküler fazında psikotik eşik düşebilmektedir (8-10). Literatür sex steroidlerinin dramatik değişimlerini göz önünde bulundurarak, özellikle östrojen üzerine yoğunlaşsa da, postpartum psikozda kanıtlanmış etyolojik bir tanımlama yapılamamıştır.

Tiroid hormonları ve postpartum psikoz ilişkisini inceleyen çalışmalar genel olarak immünolojik temelli çalışmalardır. Gebelikte fetal dokunun korunması ve gebeliğin devamı için annede immun toleransin ön planda olmasi gerekmektedir. İmmün tolerans nedeniyle, serum antikor düzeyleri önemli ölçüde azalır ve immünolojik etyoloji kaynaklı hastalıklarda iyilik hali gözlenir $(11,12)$.

İmmün kökenli, postpartum otoimmün tiroid hastalıkları (AITD) ise, doğumdan sonraki ilk 1 y1l içinde ortaya çıkmaktadır. AITD, tiroid bezinde inflamasyon ve tiroid oto antikor titrelerinde yükselme ile seyretmektedir. Hipotetik olarak postpartum dönemde immün sistem aktivasyonundaki artış ve alta yatan AITD ile psikoz aktivasyonunun kolaylaştığ1 düşünülmektedir. Postpartum psikoza eşlik eden AITD vakaları olduğu gibi, geç başlangıçlı (doğumdan 4 haftadan sonra) olguların AITD ile ilişkili olmadığını düşündüren çalışmalar da mevcuttur (11).

Kanıtlanımış etyolojik faktörler arasında, postpartum psikozu en fazla öngören durum (\%25-57 olasillkla), daha önceki gebeliklerinde geçirilen postpartum psikoz atağıdır. Ayrıca annenin medeni halinin bekar olması, ileri yaş, prenatal depresif epizod öyküsü, daha önce psikiyatrik tedavi alma ve ailede affektif psikoz hikayesi postpartum psikoz olasılı̆̆ını arttırmaktadır (13).

\section{Olası Sonuçlara Bakış}

Tedavi edilmeyen olgularda özkıyım (\%5 oranında) tabloya eşlik etmektedir. Diğer önemli bir durum ise, etkili müdahale edilmediğinde oluşabilecek bebeği öldürme davranışıdır (\%4 oranında) (14). Bebeğe verilen hayati zararlar, infantisid (1 yaş alt1 bebeğin öldürülmesi) ve neonatasid (doğumdan sonraki ilk 24 saatte bebeğin öldürülmesi)' dir (15). 1980' lerden bu yana postpartum psikoz vakalar1, bu nedenle dava konusu olabilmektedir (16). Ayrıca bozulmuş anne-bebek bağlanması, infantın kötüye kullanımı ve infantın ihmali olası sonuçlar arasindadır $(17,18)$.

Uzun dönemli seyirde; postpartum psikotik atak geçiren olguların \%72-88' inde bipolar bozukluk veya şizoaffektif bozukluk tanisı konulurken, $\% 12$ 'si ise şizofreni tanıs1 nedeniyle takip edilmektedir (19).

Bipolar bozukluk tanısı ile takip edilen olguların retrospektif değerlendirmelerinde ise, \%25-50 oranında postpartum psikoz epizodu yaşadığ 1 , şayet bu olguların ailelerinde de postpartum psikoz hikayesi varsa, riskin \%74' e kadar yükseldiği saptanmıştır (20). Sonuç olarak; çalışmalar postpartum psikozun duygudurum bozuklukları ile yakından ilişkili olduğunu göstermiştir.

\section{Önleme}

Postpartum psikoz epizodunu önlemek için kullanilan farmakolojik ajanlar mood stabilizatörleri, antidepresanlar, antipsikotikler ve hormonoterapiler ile sinırlidır. Mevcut ajanlarla yapılan, vaka serileri ve karşılaştırmalı kontrol grup çalışmaları mevcuttur. Olgular daha önce postpartum psikoz epizodu yaşamış, bipolar bozukluk ve şizoafektif bozukluk tanısı almış olan dolayısıyla postpartum psikoz ortaya çıma olasılığı yüksek gruptan seçilmiştir.

Bilszta ve ark.'nın (21) yaptığı vaka-kontrol grubu karşılaştırmalı çalışmada, tedavide mood stabilizatörleri, antipsikotik ve antidepresanlar kullanılmıştır. Sonuç olarak, risk grubundaki olgularda mood stabilizatörü kullananlarda relapsin önlendiği gözlenmiştir. Lityum bipolar bozuklukta oldukça sık kullanılan bir ajandır. Psikotik tablo ile bipolar bozukluk arasında ilişki 
olduğu düşünüldüğünde, yinelemeleri önlemek ve tedavi açısından lityum ilk tercihler arasındadır. Lityuma gebeliğin son 3 aylık döneminde ya da doğumdan hemen sonra başlanması önerilmektedir (22).

Kumar ve ark.'nın (23) yaptığ1 vaka serisinde; bipolar 1, bipolar 2 ve şizoaffektif bozukluk tanıs1 almış olgular üç gruba ayrılmış ve bu gruplardaki olgulara sirasiyla $200 \mathrm{mg} / \mathrm{dl}, 400 \mathrm{mg} / \mathrm{dl}$ ve 800 $\mathrm{mg} / \mathrm{dl}$ dozunda proflaktik transdermal östrojen uygulanmıştır. $\mathrm{Bu}$ çalışmada 12 hastada postpartum psikoz relaps1 gelişmiştir. Relaps gelişen ve $800 \mathrm{mg} / \mathrm{dl}$ östrojen alan olgularda daha düşük doz antipsikotik ile tedaviye yanıt alınmış. Ayrıca $800 \mathrm{mg} / \mathrm{dl}$ östrojen alan olgular diğer hospitalize olgulara göer daha kisa sürede hastaneden taburcu olmuşlardır.

\section{Tedavi}

Postpartum psikoz tedavisinde en uygun yaklaşım olguların hospitalize edilerek tedavi edilmesidir. Pospartum psikozun tedavisinde; mood stabilizatörleri, antipsikotikler, antidepresanlar, hormonoterapinin yan1 sira, $\beta$ - blokerler ve EKT (elektrokonvülsif tedavi) tedavi seçenekleri arasinda yer alır.

EKT farmakoterapiye dirençli birçok psikiyatrik hastalıkta kullanılabilmektedir. Postpartum psikozda EKT, özellikle şiddetli özkıyım riskinin eşlik ettiği vakalarda uygulanır (24).

Hormon replasmanının tedavide faydalı olduğunu gösteren vaka serileri mevcuttur. Ancak hormonal faktörlerin postpartum psikoz tedavisindeki yerini anlamamız açısından daha fazla çalışmaya ihtiyaç vardır (25).

Postpartum psikoz belirtileri uygun tedavi ile yaklaşık 2 ayda tamamen düzelmektedir. Hastalığın tekrarlama ihtimalinin yüksek olduğu olgularda koruyucu tedavi planlanmasinın yapilmasi uygun bir yaklaşım olacaktır.

Sonuç olarak, postpartum psikoz nadir görülmesine rağmen, anne ve bebek için geri dönüşümsüz hayati sonuçlar doğurabilecek psikiyatrik acil bir durumdur. Tedavi için yapılacak müdahalenin olabildiğince hızlı bir şekilde yapılması ve olguların hospitalize edilmesi en uygun yaklaşımdir. Postpartum psikoz için riskli grubun, gebelik ve lohusalık döneminde erken tespit edilip, takiplerinin s1k aralıklarla yapılması ve bu riskli grubun yakınlarına psiko-eğitim verilmesi tedaviyi kolaylaştıracaktır.

\section{Kaynaklar}

1. Marrs CR, Durette RT, Ferraro DP, Cross CL. Dimensions of postpartum psychiatric distress: preliminary evidence for broadening clinical scope. J Affect Disord 2009; 115(1-2): 100-11.

2. Sit D, Rothschild AJ, Wisner KL. A review of postpartum psychosis. J Womens Health 2006; 15(4): 352-368.

3. Rhode A, Marneros A. Postpartum psychoses: onset and longterm course. Psychopathology 1993; 26(3-4): 203-9.

4. Heron J, McGuinness M, Blackmore ER, Craddock N, Jones I. Early postpartum symptoms in puerperal psychosis. BJOG 2008; 115(3): 348-353.

5. Wisner KL, Peindl K, Hanusa BH. Symptomatology of affective and psychotic illness related to childbearing. J Affect Disord 1994; 30(2): 77-87.

6. Connell M. The postpartum psychosis defense and feminism: more or less justice for women? Case W Res L Rev 2002; 53: 143.

7. Sharma V, Smith A, Khan M. The relationship between duration of labour, time of delivery, and puerperal psychosis. J Affect Disord 2004; 83(23): $215-220$.

8. Faraone SV, Chen WJ, Goldstein JM, Tsuang MT. Gender differences in age at onset of schizophrenia. The British Journal of Psychiatry 1994: 164 (5): 625-629.

9. Bergemann N, Parzer P, Runnebaum B, Resch F, Mundt C. Estrogen, menstrual cycle phases, and psychopathology in women suffering from schizophrenia. Psychol Med 2007; 37(10): 14271436.

10. Rubin LH, Carter CS, Drogos L, PournajafiNazarloo H, Sweeney JA, Maki PM. Peripheral oxytocin is associated with reduced symptom severity in schizophrenia. Schizophr Res 2010; 124(1-3): 13-21.

11. Bokhari R, Bhatara VS, Bandettini F, McMillin JM. Postpartum thyroiditis. Psychoneuroendocrinology 1998; 23(6): 643-50.

12. Luppi P. How immune mechanism are affected by pregnancy. Vaccine 2003; 21(24): 3352-3357.

13. Essali A, Alabed S, Guul A, Essali N. Preventive intervention for postnatal psychosis. Schizophrenia Bulletin 2013; 39(4): 748-750.

14. Parry BL. Postpartum psychiatric syndromes, in Comprehensive Textbook of Psychiatry (ed 6,vol ). Edited by Kaplan H, Sadock B. Philadelphia: Williams\&Wilkins, 1995, pp 1059-66.

15. Resnick PJ. Child murder by parents: a psychiatric review of filicide. Am J Psychiatry 1969; 126(3): 73-82. 
16. Nau ML, McNiel DE, Binder RL. Postpartum psychosis and the courts J Am Acad Psychiatry Law 2012; 40(3): 318-325.

17. Hipwell AE, Goossens FA, Melhuish EC, Kumar R. Severe maternal psychopathology and infantmother attachment. Dev Psychopathol 2000; 12(2): 157-175.

18. Chandra PS, Bhargavaraman RP, Raghunandan VNPG, Shaligram D. Delusions related to infant and their association with mother- infant interactions in postpartum psychotic disorders. Arch Womens Ment Health 2006; 9(5): 285-288.

19. Sit D, Rothschild AJ, Wisner KL. A review of postpartum psychosis. J Women's Health 2006; 15(4): 352-368.

20. Jones I, Craddock N. Familiarity of the puerperal triger in bipolar disorder: results of a familiy study. Am J Psychiatry 2001; 158(6): 913-917.

21. Bilszta JLC, Meyer D, Buist AE. Bipolar affective disorder in the postnatal period: investigating the role of sleep. Bipolar Disord 2010; 12(5): 568 578.

22. Stewart DE, Klompenhouwer JL, Kendell RE, van Hulst AM. Prophylalactic lithium in puerperal psychosis. The experience of three centres. Br J Psychiatry 1991; 158(3): 393-397.

23. Kumar C, Mclvor RJ, Davies T, Brown N, Papadopoulos A, Wieck A, et al. Estrogen administration does not reduce the rate of reccurrence of afective psychosis after childbird. J Clin Psychiatry 2003; 64(2): 112-118.

24. Grigoridas S. Postpartum and its mental health problems. Romans SE, Seeman MV (eds.) Women's Mental Health. Philadelphia; Lippincott, Williams and Wilkins 2006; 283-296.

25. Huang MC, Wang YB, Chan CH. Estrogenprogestrone combination for treatmentrefractory postpartum mania. Psychiatry Clin Neurosci 2008; 62(1): 126. 